Gelanggang Olahraga: Jurnal Pendidikan Jasmani dan Olahraga

Volume 2, Nomor 2, Januari-Juni 2019

e-ISSN : 2597-6567

p-ISSN : 2614-607X

DOI : https://doi.org/10.31539/jpjo.v2i2.714

\title{
PERANAN PSIKOLOGI OLAHRAGA DALAM PENCAPAIAN PRESTASI ATLET SENAM ARTISTIK KABUPATEN SIJUNJUNG
}

\author{
Sri Gusti Handayani \\ Program Studi Pendidikan Olahraga, Universitas Negeri Padang \\ handayanisrigusti@gmail.com
}

\begin{abstract}
ABSTRAK
Tujuan Penelitian ini adalah untuk melihat sejauhmana peranan psikologi olahraga dalam senam artistik. Jenis penelitian ini adalah kualitiatif. Data didiambil melaui observasi dan wawancara dengan menggunakan angket skala likert yang diberikan kepada atlet, dan analisis data dilakukan dengan analisi deskriptif. Hasil penelitian menunjukkan di dalam pembinaan olahraga senam di Kabupaten Sijunjung, aspek psikologis atlet yang meliputi emosi, intelegensi, kecerdasan, ketegangan, disiplin, agresivitas, percaya diri, motivasi, masih berada dalam kategori kurang, hal ini disebabkan kafrena aspek psikologi atlet kurang diperhatikan oleh pelatih dalam pembinaan olahraga senam artistik. Simpulan, aspek psikologi sangat dibutuhkan dalam mendukung prestasi atlet senam artistik
\end{abstract}

Kata Kunci: Psikologi, Senam Artistik, Prestasi Atlet

\begin{abstract}
The purpose of this study was to see the extent of the role of sports psychology in artistic gymnastics. This type of research is qualitative. Data were taken through observation and interviews using a Likert scale questionnaire given to athletes, and data analysis was carried out by descriptive analysis. The results showed that in the training of gymnastics in Sijunjung Regency, the psychological aspects of athletes which included emotion, intelligence, intelligence, tension, discipline, aggressiveness, self-confidence, motivation, were still in the less category, this was due to the lack of attention paid coach in fostering artistic gymnastics. Conclusion, the psychological aspect is very much needed in supporting the artistic gymnastics athlete's presentation
\end{abstract}

Keywords: Psychology, Artistic Gymnastics, Athlete Achievement

\section{PENDAHULUAN}

Dewasa ini terlihat perkembangan olahraga terjadi dengan sangat pesat. Banyak cabang olahraga baru yang akan dikembangkan di Indonesia. Hal ini tidak terlepas dari semakin banyaknya minat masyarakat terhadapolahraga yang ada. Mulai dari olahraga kesehatan, olahraga rekreasi hingga olahraga prestasi. Olahraga prestasi dilakukan untuk mencapai prestasi yang maksimal pada suatu cabang olahraga. Untuk mecapai prestasi yang maksimal dibutuhkan pembinaan yang baik pada semua unsur pencapaian prestasi. Prestasi merupakan tujuan 
utama yang ingin dicapai dalam pembinaan olahraga. Prestasi adalah hasil yang telah dicapai seseorang dalam melakukan kegiatan. Hal ini sejalan dengan UU RI No.3 Tahun 2005 Tentang Sistem Keolahragaan Nasional "Prestasi adalah hasil upaya maksimal yang dicapai olahragawan atau kelompok olahragawan (tim) dalam kegiatan olahraga". Banyak hal yang ikut berperan dalam pencapaian prestasi tersebut, diantaranya : sarana dan prasarana, pembinaan yang dilakukan, finansial, dukungan orangtua, status ekonomi keluarga, organisasi yang mengelola, pelatih, program latihan, aspek fisik, teknik, taktik dan mental. Sejalan dengan pendapat Kementrian Negara Pemuda dan Olahraga Republik Indonesia (Kemenegpora RI, 2006)

prestasi bisa tercapai, apabila memenuhi beberapa komponen seperti: atlet potensial, selanjutnya dibina dan diarahkan oleh sang pelatih. Untuk memenuhi sarana dan prasarana latihan dan kebutuhan kesejahteraan pelatih dan atlet perlu perhatian dari pembina/pengurus induk cabang olahraga. Untuk melihat dan mengevaluasi hasil pembinaan, perlu memberikan uji coba dengan melakukan kompetisi dan try out baik di dalam negeri maupun di luar negeri dengan tujuan mengukurkemampuan bertanding/berlomba dan kematangan sebagai pembentukan teknik, fisik, dan mental bertanding. Tetapi perlu diingat bahwa aktivitas komponenkomponen di atas bisa berjalan apabila ditunjang oleh pendanaan yang profesional serta penggunaannya harus dengan penuh tanggung jawab

Dari pendapat di atas dapat dijelaskan bahwa keadaan mental atau psikologi atlet termasuk ke dalam komponen penentu tercapainya sebuah prestasi. Banyak studi yang menunjukkan betapa pentingnya peranan psikologis ketika meningkatkan kemampuan seorang atlet dalam menghadapi situasi pertandingan. Perubahan psikologis saat petandingan yakni meningkatnya kemampuan atlet dalam menerima stress (tekanan), tetap berkonsentrasi, memiliki ketegaran mental (mental toughness) sehingga mampu mengatasi tentangan yang lebih berat (Sukadiyanto, 2011).

Mental juga sangat dibutuhkan dalam cabang senam artistik. Senam artistik merupakan salah satu cabang senam yang butuh konsentrasi tinggi dalam pertandingan. Senam artistik merupakan olahraga individu dan grup yang tidak memiiki kontak langsung dengan orang lain. Senam artistik dinilai dari keindahan gerakan yang dilakukan serta kesulitasn gerakan yang dilakukan atlet. Untuk menghasilkan gerakan yang bagus, maka mental yang kuat menjadi pokok utama dalam pertandingan, misalkan saat gagal melakukan salah satu gerakan dalam rangkaian gerakannya, atlet tetap harus fokus untuk melakukan gerakan selanjutnya, dan tidak terpengaruh oleh kegagalan gerakan yang sebelumnya. Oleh karena itu faktor psikologi sangat perlu diperhatikan dalam cabang olahraga senam artistik ini.

Berdasarkan observasi dilapangan, terlihat bahwa terjadi penurunan prestasi dari beberapa tahun terakhir, kurangnyaperolehan medali pada cabang olahraga senam artistik pada setiap pekan olahraga Provinsi yang diadakan, hal ini salah satunya disebabkan oleh faktor psikologi yang masih kurang diperhatikan oleh pelatih. Saat melakukan gerakan atlet terlihat menghafalkan gerakan, buka memahami gerakan yang akan dilakukan, sehingga atlet terlihat tertekan dan 
strees saat akan melakukan gerakan yang sulit. Untuk itu, psikologi dalam olahraga perlu dilihat secara mendalam sehingga prestasi atlet bisa lebih bagus lagi.

\section{KAJIAN TEORI}

Psikologi adalah ilmu yang mempelajari tentang perilaku seseorang. Psikologi juga disebut sebagai disiplin ilmu yang mempelajari mental, pikiran, dan perilaku manusia. Jika dihubungkan dengan olahraga, maka akan mencakup perilaku yang diperlihatkan oleh seseorang ketika sedang berolahraga, atau disebut dengan penampilannya (performance) dalam berolahraga.dengan psikologi yang baik maka akan menghasilkan performance yang baik juga. Singer, R.N. (1980) mengemukakan secara singkat bahwa Psikologi Olahraga adalah "the science of psychoogy applied to athletes and athletic situations"; dan Cox) R.H. (1986) mengemukakan bahwa Sport Psychology is a science in which the principles of psychology are applied in a sport setting”.

Dengan kata lain dapat diartikan psikologi olahraga adalah ilmu psikologi yang diterapkan dalam bidang olahraga, meliputi faktor-faktor yang berpengaruh secara langsung terhadap atlet dan faktor-faktor di luar atlet yang dapat mempengaruhi penampilan atlet.

Jadi, Psikologi Olahraga pada hakikatnya adalah psikologi yang diterapkan dalam bidang olahraga, meliputi faktor-faktor yang berpengaruh secara langsung terhadap atlet dan faktor-faktor di luar atlet yang dapat mempengaruhi penampilan (performance) atlet tersebut. Weinberg, R.S. \& Gould, D. (1995) mengemukakan bahwa "Sport and exercise psychology is the scientific study of people and their behavior in sport and exercise context". Secara garis besar, kegiatannya adalah: 1) mempelajari bagaimana faktor psikologis mempengaruhi penampilan fisik seseorang, 2) memahami bagaimana keterlibatan seseorang dalam olahraga mempengaruhi perkembangan psikis, kesehatan, dan kesejahteraan psikisnya. Jika dihubungkan dengan olahraga prestasi, pengertian ini jelas menunjukkan bahwa penampilan (performance) seorang atlet dipengaruhi oleh berbagai faktor psikologis. Baik pengaruhnya positif dalam arti penampilan menjadi baik, maupun negatif dalam arti penampilan menjadi buruk. Ini adalah faktor psikologis, yang sering kali disebut faktor psikis atau faktor mental.

Faktor psikis ini dapat bersifat langsung dan tidak langsung. Secara langsung, misalnya karena ada ketegangan emosi yang berlebihan sehingga mempengaruhi seluruh penampilan atlet senam dalam melakukan rangkaian gerakan pada alat lantai. Sedangkan secara tidak langsung berkaitan dengan penampilan atlet, atau yang disebut dengan faktor non-teknis, contohnya, sebelum masuk ke arena pertandingan, terjadi pertengkaran yang menegangkan aspek emosinya. Saat bertanding, kondisi emosinya yang bergejolak tersebut akan berpengaruh negatif terhadap penampilannya. Contoh lainnya adalah penggunaan peralatan yang diperlukan untuk bertanding, seperti baju yang tidak nyaman. Hal tersebut tentu akan mempengaruhi penampilannya. Lingkungan tempat atlet bertanding seperti kondisi lapangan ataupun penonton juga dapat mempengaruhi kondisi psikis atlet, baik secara positif maupun secara negatif.

James dalam Syafrudin (2011) mengemukakan bahwa 50\% dari hasil pertandingan ditentukan oleh faktor mental dan psikologis. Kemudian Gunarsa (2004) mengemukakan bahwa penampilan atlet dalam permainan atau 
pertandingan tidak dapat dilepaskan dari tingkahlaku dan aspek psikis yang mendasarinya. Kondisi fisik yang meliputi kekuatan, kelentukan, kecepatan, dayatahan, dan power otot, struktur anatomis-fisologi dan ketrampilan yang tinggi tidak cukup, karena harus ada yang mengemudikan dan mengarahkan, sehingga penampilannya merupakan perpaduan antara berbagai faktor, di mana faktor psikis acapkali menjadi penentu dan berperan lebih besar. Cooper (1969) mengemukakan bahwa gejala atau aspek-aspek psikis yang berpengaruh dan dapat dikembangkan pada diri atlet adalah; 1) kemantapan emosi, 2) keuletan (agresif), 3) motivasi dan semangat, 4) disiplin, 5) percaya diri, 6) keterbukaan, dan 7) kecerdasan. Berikut ini dijelaskan masing-masing aspek psikis tersebut:

\section{Aspek emosi}

Emosi adalah keadaan mental yang ditandai oleh perasaan yang kuat dan diikuti ekspresi motorik yang berhubungan dengan suatu objek atau situasi eksternal. Tingkat emosi seseorang atlet akan berubah dari waktu ke waktu dan sangat tergantung terhadap tekanan mental yang dihadapi atlet pada saat itu.James Drever (1971) mengemukakan bahwa emosi ditandai adanya perasaan yang kuat, biasanya merupakan dorongan terhadap bentuk-bentuk tingkahlaku tertentu. Apabila atlet terganggu dengan hebat akan mempengaruhi fungsi intelektualnya, hal ini akan berpengaruh terhadap penampilan atlet. Kemampuan atlet menerima rangsangan emosional seperti pujian, ejekan, cemohan, ancaman, baik penonton, pelatih atau teman-temannya akan menentukan kuat lemahnya mental atlet, karena mental atlet meliputi keseluruhan proses kejiwaan yang terorganisir, sehingga gangguan pada aspek emosional akan berpengaruh terhadap kondisi mental secara keseluruhan. Ketidakstabilan emosi akan mengakibatkan terjadinya psychological instability dan keadaan mental akan menjadi goyah, tidak stabil, sering berubah pendirian dan pada waktu bertanding konsentrasinya seringkali kacau, dan dampaknya prestasi tidak ada atau kalah dalam pertandingan. Pengendalian emosi pada waktu bertanding atau bermain sangat penting dilakukan oleh seorang atlet.

Gejolak emosi biasanya ditandai dengan adanya ketegangan (stress), takut, marah, gembira, muak, kecewa, dan rasa cemas. Walaupun emosi menjadi momok bagi atlet, namun kalau emosi tersebut dapat ditekan dan dikelola dengan baik maka akan menjadi emosi positif yang dapat meningkatkan motivasi, semangat dan daya juang yang tinggi, sehingga dapat menghilangkan perasaan tegang, cemas, marah, takut, kecewa, sehingga kemenangan dan prestasi dapat diraih.

Pengendalian emosi dalam pertandingan olahraga seringkali menjadi faktor penentu kemenangan. Para pelatih harus mengetahui dengan jelas bagaimana gejolak emosi atlet asuhannya, bukan saja dalam pertandingan tetapi juga dalam latihan dan kehidupan sehari-hari. Pelatih perlu tahu kapan dan hal apa saja yang dapat membuat atletnya marah, senang, sedih, takut, dan sebagainya. Dengan demikian pelatih perlu juga mencari data-data untuk mengendalikan emosi para atlet asuhannya, yang tentu saja akan berbeda antara atlet yang satu dengan atlet lainnya.

Gejolak emosi dapat mengganggu keseimbangan psikofisiologis seperti gemetar, sakit perut, kejang otot, dan sebagainya. Dengan terganggunya keseimbangan fisiologis maka konsentrasi pun akan terganggu, sehingga atlet tidak dapat tampil maksimal. Seringkali seorang atlet mengalami ketegangan yang 
memuncak hanya beberapa saat sebelum pertandingan dimulai. Demikian hebatnya ketegangan tersebut sampai ia tidak dapat melakukan awalan dengan baik. Apalagi jika lawannya dapat menekan dan penonton pun tidak berpihak padanya, maka dapat dibayangkan atlet tersebut tidak akan dapat bermain baik. Konsentrasinya akan buyar, strategi yang sudah disiapkan tidak dapat dijalankan, bahkan ia tidak tahu harus berbuat apa.

Dalam cabang olahraga senam artistik, gejolak emosi akan memberikan pengaruh yang sangat besar terhadap performance dan prestasi atlet. Jika atlet merasa cemas dan gugup nsaat melakukan gerakan, misalkan pada alat beam (balok keseimbangan), maka atlet tidak akan bisa meakukan gerakan dengan benar dan akan terjatuh sehingga menimbulkan cedera pada atlet tersebut.

\section{Aspek agresivitas.}

Agresivitas merupakan salah satu bentuk perilaku yang dimiliki oleh setiap orang. Agresivitas biasa juga disebut dengan giat atau keuletan adalah suatu tindakan yang dilakukan atas motif dan motivasi yang tinggi dalam diri seseorang atau atlet. Keuletan yang dimiliki oleh seseorang sangat tinggi pengaruhnya terhadap pencapaian prestasi. Karena keuletan seseorang atau atlet mempunyai keinginan yang tinggi untuk melakukan suatu tugas atau latihan yang berat untuk mencapai suatu tujuan. Warchel dan Cooper dalam Syafrudin (2011) ,membagi aspek agresivitas menjadi dua yaitu; 1) agresivitas yang terkontrol dan 2). Agresivitas yang tidak terkontrol. Agresivitas yang terkontrol dengan ketat akan menunjukkan adanya kontrol yang ekstrem terhadap tingkahlaku agresif dalam berbagai kondisi, sedangkan agresivitas yang tidak terkontrol menunjukkan kurangnya larangan terhadap pengungkapan tingkahlaku agresif dan kecendrungan untuk mengadakan respons terhadap frustrasi dengan tindakantindakan agresif.

Agresif hanyalah merupakan salah satu dari sifat-sifat seorang pemain. Kecenderungan sifat agresif pemain menjadi tindakan positif yang dibutuhkan untuk memenangkan suatu pertandingan atau sebaliknya menjadi tindakan destruktif. Dalam cabang senam artistik, agresitiviatas terlihat jika seorang atlet ingin mempelajari suatu gerakan baru yang memiliki tingkat kesulitas lebih tinggi dari gerakan sebelumnya, misalkan atlet ingin melakukan gerakan salto twis, dengan bagitu atlet akan terus mencoba melakuan teknik dasar gerakan tersebut, secara berulang-ulang tanpa merasa bosan dan jenuh hingga atlet tersebut bisa melakukan gerakan twis itu.

\section{Aspek Motivasi}

Motivasi dapat dilihat sebagai suatu proses dalam diri seseorang untuk melakukan sesuatu sebagai usaha dalam mencapai tujuan tertentu. Motivasi yang kuat menunjukkan bahwa dalam diri orang tersebut tertanam dorongan kuat untuk dapat melakukan sesuatu.Prestasi atlet merupakan hasil penambahan antara latihan dan motivasi atlet, sehingga motivasi ini dipandang penting dalam mencapai tujuan yaitu atlet berprestasi maksimal. Tanpa motivasi tidak akan ada prestasi yang muncul seperti yang dinyatakan oleh Cratty melalui penelitian mengenai kecemasan dan motivasi terhadap prestasi olahraga menunjukkan bahwa tingkat kecemasan rendah dan motivasi tinggi menghasilkan penampilan olahraga yang meningkat. 
Motivasi merupakan proses aktualisasi sumber penggerak dan pendorong tingkah laku individu memenuhi kebutuhan untuk mencapai tujuan tertentu. Motivasi olahraga diartikan keseluruhan daya penggerak (motif-motif) di dalam diri individu yang menimbulkan kegiatan berolahraga, menjamin kelangsungan latihan dan memberi arah pada kegiatan latihan untuk mencapai tujuan yang dikehendaki (Gunarsa, 2004).

Terdapat dua jenis motivasi dalam olahraga yaitu motivasi intrinsik dan ekstrinsik. Motivasi intrinsik merupakan dorongan yang kuat dari dalam yang menyebabkan individu berpartisipasi. Atlet yang mempunyai motivasi intrinsik biasanya mempunyai kepribadian yang matang, jujur, sportif, tekun, percaya diri, disiplin dan tahan lama. Motivasi intrinsik inilah yang harus selalu ditumbuh kembangkan dalam diri anak, sayangnya motivasi ini sulit dipelajari. Sedang motivasi ekstrinsik merupakan dorongan berasal dari luar individu yang menyebabkan seseorang berpartisipasi dalam olahraga, contohnya dorongan dari pelatih, teman, orang tua, guru, kelompok, bangsa, hadiah, bonus, uang, dsb. Dorongan semacam ini biasanya tidak bertahan lama.

Dalam pertandingan ataupun latihan motivasi ini harus terjaga tetap tinggi agar hasilnya meningkat. Ada beberapa teknik untuk meningkatkan atau menaikkan motivasi atlet antara lain dengan teknik verbal, tingkah laku, insentif, supertisi, dan citra mental. Teknik verbal berarti dalam memberi motivasi pada atlet dengan menggunakan tutur kata sebagai alatnya. Hal ini dapat dilakuklan melalui pembicaraan, diskusi, pendekatan individual. Teknik tingkah laku merupakan cara untuk memotivasi atlet melalui contoh atau keteladan dari pelatih dalam tingkahlaku sikap perbuatan agar dicontoh oleh atletnya. Teknik insentif yaitu cara memotivast atlet dengan adanya "iming-iming" berujud uang atau benda lain, namun dapat juga dalam bentuk hadiah. Teknik supertisi merupakan kepercayaan akan sesuatu yang secara logis atau ilmiah tidak diterima, namun dianggap membawa keberuntungan dalam pertandingan/latihan. Secara citra mental dimaksudkan melatih atlet membuat gerakan- gerakan yang benar melalui imajinasi, setelah gerakan-gerakan dimatangkan dalam imajinasi kemudian benarbenar dilaksanakan untuk dievaluasi.

Dalam cabang olahraga sebam artistik, imajery ini sangat dibutuhkan atlet, karena dengan membayangkan gerakan yang bagus, maka atlet akan mencoba meakukan gerakan yang telah dibayangkannya tadi, analisis kesalah dengan imajery ini akan emmberikan dampak yang baik terhadap atlet senam artistik. Dengan pendekatan psikologis diharapkan atlet dalam setiap penampilannya dapat memperlihatkan motivasi yang kuat untuk bermain sebaik-baiknya, sehingga melakukan yang terbaik dan dapat memenangkan pertandingan. Oleh karena itu, pelatih harus memperlihatkan bahwa ia menghargai hasil kerja atlet secara konsekuen.

\section{Kecerdasan (Intelegensi)}

Kecerdasan (intelegensi) seorang atlet dalam olahraga sangat dibutuhkan, utamanya pada cabang olahraga yang memerlukan keterampilan teknik tinggi, taktik dan strategi bermain yang komplkes. Aspek kecerdasan mempunyai kadar yang berbeda-beda antara satu cabang olahraga dengan cabang olahraga lainnya seperti; cabang olahraga bolavoli, sepakbola, sepaktakraw dan bolabasket membutuhkan kecerdasan lebih banyak dibandingkan cabang olahraga gulat, 
angkat besi, menembak dan sebagainya. Kecerdasan yang tinggi akan berpengaruh terhadap tingkat kemampuan seseorang atlet untuk mengatasi problema yang dihadapi dalam latihan dan pertandingan. Atlet yang memiliki kecerdasan tinggi akan lebih mudah dan cepat menemukan solusi mengatasi problema yang terjadi dalam latihan dan petandingan dibandingkan atlet yang memiliki tingkat kecerdasan rendah.

\section{Kepercayaan diri (self confidence)}

Kepercayaan diri atau percaya diri adalah salah satu aspek kejiwaan yang harus dimiliki oleh seorang atlet dan aspek ini termasuk banyak menentukan penampilan atlet di lapangan. Sudibyo (1993) mengemukakan bahwa untuk dapat berprestasi tinggi, atlet harus memiliki rasa percaya diri, percaya bahwa ia sanggup dan mampu untuk mencapai prestasi yang diinginkan. Percaya diri merupakan modal utama setiap atlet untuk mencapai prestasi setinggi-tingginya. Tingkat percaya diri atlet berbeda-beda antara satu dengan lainnya, sehingga hal ini perlu mendapat perhatian dari pelatih. Bagi atlet pemula perlu diberi kesempatan lebih banyak untuk meningkatkan kepercayaan dirinya dengan mengikuti banyak pertandingan.

Perbedaan kepercayaan diri dapat dibedakan menjadi 3 yaitu' 1) over confidence, 2) lack confidence, dan 3) full confidence. Over confidense adalah rasa percaya diri yang berlebihan yang dimiliki atlet. Segi negatif yang bisa ditimbulkan oleh over confiedence pada suatu pertandingan adalah sering menganggap enteng lawan atau muncul rasa sombong dan menganggap lawan lebih rendah dari dirinya. Karena harapan sukses terlalu tinggi tersebut, maka apabila mengalami kekalahan atlet yang bersangkutan kurang siap mental menerima kekalahan tersebut dan mudah frustrasi. Segi positifnya pada suatu pertandingan adalah ketegangan dan rasa cemas menghadapi lawan tidak muncul. Lack confidence atau rasa kurang percaya diri adalah kurang menguntungkan dalam pertandingan, karena kurang percaya diri ini merupakan tumpuan yang lemah untuk dapat mencapai prestasi tinggi. Kurang percaya diri berarti atlet meragukan kemampuannya, akibatnya timbul rasa tegang, cemas dan takut menghadapi lawan, kalau hal seperti ini muncul maka besar kemungkinan atlet tersebut mengalami kekalahan.

Kegalan-kegalan yang sering dialami atlet yang kurang percaya diri, akan mudah menimbulkan rasa putus asa dan apabila dituntut mencapai prestasi yang lebih tinggi namun tidak berhasil akan dapat menimbulkan frustrasi. Full confidence adalah rasa penuh percaya diri. Sifat ini perlu ditanamkan pada atlet, karena rasa penuh percaya diri yang dimiliki atlet merupakan modal utama untuk menghadapi pertandingan. Rasa penuh percaya diri timbul karena didasari atas kemampuan yang dimiliki atlet dan hal ini disadari oleh atlet tersebut. Singer (1980) mengemukakan bahwa tanpa memiliki rasa percaya diri sendiri, atlet tidak akan mencapai prestasi tinggi. Hal ini disebabkan karena ada saling hubungan antara motif berprestasi dan percaya diri.

Percaya diri adalah percaya bahwa ia sanggup dan mampu untuk mencapai prestasi tertentu: apabila ia prestasinya sudah tinggi maka individu atau atlet yang bersangkutan akan lebih percaya. Dalam olahraga, kepercayaan diri sudah pasti menjadi salah satu faktor penentu suksesnya seorang atlet. Masalah kurang atau hilangnya rasa percaya diri terhadap kemampuan diri sendiri akan mengakibatkan 
atlet tampil di bawah kemampuannya. Karena itu sesungguhnya atlet tidak perlu merasa ragu akan kemampuannya, sepanjang ia telah berlatih secara sungguhsungguh dan memiliki pengalaman bertanding yang memadai.

Peran pelatih dalam menumbuhkan rasa percaya diri atletnya sangat besar. Syarat untuk untuk membangun kepercayaan diri adalah sikap positif. Beritahu pemain di mana letak kekuatan dan kelemahannya masing-masing. Buatkan program latihan untuk setiap atlet dan bantu mereka untuk memasang target sesuai dengan kemampuannya agar target dapat tercapai jika latihan dilakukan dengan usaha keras. Berikan kritik membangun dalam melakukan penilaian terhadap atlet., dan sebaliknya kritik negatif akan bisa mengurangi rasa percaya diri atlet. Dalam cabang olahraga senam artistik, misalkan saat latihan atlet belum bisa melakukan gerakan salto kedepan, maka pelatih selalu memberikan kata-kata penguatan kepada atlet, bahwa atlet itu bisa melakukannya dengan didukung oleh analisis gerakan yang baik juga.

\section{Ketegangan (stress)}

Ketegangan atau yang lebih dikenal dengan istilah "stress" adalah suatu tekanan yang terasa menekan dalam diri seseorang atau atlet. Perasaan tertekan ini timbul karena banyak faktor yang berasal dari dalam diri sendiri atau dari luar Gunarsa (2004). Kemudian Singer (1980) mengemukakan bahwa ketegangan telah menjadi perhatian para ahli psikologi olahraga. Telah diakui bahwa ketegangan berkembang sejalan dengan peristiwa keolahragaan dan tidak dapat dihindari. Dalam olahraga kompetitif akan muncul situasi tegang yang potensial. Atlet yang tegang akan mengalami gangguan pada penampilannya. Tetapi menjelang pertandingan, diperlukan ketegangan dalam batas-batas tertentu, agar atlet itu siap menghadapi dan melaksanakan tugas secara hati-hati dan baik. Tanpa ketegangan menjelang pertandingan, akan dapat dikatakan atlet tersebut masih tidur secara psikis, sehingga ia tidak akan mampu berbuat banyak dalam tugasnya. Ketegangan (stress) akan terjadi pada diri atlet apabila atlet mengalami hambatan dalam usaha mencapai atau memenuhi kebutuhan untuk mendapatkan kepuasan mencapai tujuan yang diinginkan. Ditinjau dari proses psikologik, setiap konflik yang terjadi dalam diri atlet akan dapat menimbulkan stress. Hambatan-hambatan yang dapat menimbulkan stress tersebut dapat datang dari dalam diri atlet itu sendiri atau dapat juga datang dari luar diri atlet. Perkembangan stress diperlukan untuk perkembangan dan kemajuan aspek psikis atlet.

\section{Kecemasan}

Rasa cemas adalah suatu perasaan subyektif akan ketakutan dan meningkatnya kegairahan secara fisiologik. al ini mirip dengan konsep takut. Seorang atlet yang mengalami rasa cemas, selama pertandingan akan mengalami kenaikan tingkatan kegairahan, perasaan tegang dan takut. Perasaan cemas atau anxiety kalau dilihat dari kata anxiety berarti tercekik. Sudibyo (1993) mengemukakan bahwa stress yang berlangsung terus menerus dapat menimbulkan kecamasan. Rasa cemas bisa muncul pada atlet sebelum pertandingan dan sesudah pertandingan. Perasaan cemas yang dirasakan oleh setiap atlet berbeda antara satu dengan yang lainnya, biasanya disebabkan oleh pengalaman dari setiap atlet.

D. Gould dalam Fisher (1976) alam penelitiannya pada atlet gulat ditemukan bahwa keadaan cemas meningkat terus sampai beberapa menit sebelum 
pertandingan dan kemudian menurun dengan cepatnya. Kecemasan selama pertandingan akan berpengaruh bila atlet tidak memiliki keseimbangan antara situasi pertandingan dengan kesanggupan atlet merespon situasi tersebut. Bilamana atlet mampu mengatasi dan memberikan respons yang baik selama berlangsung pertandingan, maka atlet akan mengatasi timbulnya rasa cemas yang tinggi.

\section{Disiplin}

Disiplin adalah sikap atau kesediaan psikologik untuk menepati atau mendukung nilai-nilai atau norma yang berlaku. Atlet yang disiplin akan berusaha untuk menepati ketentuan, tata-tertib, peraturan-peraturan dan biasanya juga patuh kepada pembuat peraturan (pelatih dan pembina). Atlet yang memiliki disiplin diri sadar untuk melakukan latihan sendiri, tanpa ada yang memerintah dan mengawasi; karena sudah memiliki rasa tanggungjawab untuk mendukung nilainilai yang dianggapnya baik dan tepat untuk dilakukan. Sikap untuk menepati dan mendukung nilai-nilai adalah sikap yang mengandung rasa tangggungjawab untuk kelangsungan nilai-nilai yang dianutnya; sehubungan dengan itu atlet yang bersangkutan tidak akan mengingkari dan membiarkan nilai-nilai tersebut direndahkan oleh orang lain.

Disiplin semu juga dapat terjadi pada diri atlet, yaitu kepatuhan untuk menepati ketentuan dan tata tertib yang dilakukannya hanya pada saat ada orang lain mengawasinya. Tindakan patuh pada ketentuan dan tata tertib tersebut dilakukan dengan terpaksa, tanpa adanya kesadaran; oleh karena itu segera pengawasan tidak ada atau kendor, maka porak-porandalah segala peraturan dan tata tertib bagi atlet yang bersangkutan. Menanamkan disiplin tidak harus dengan sikap otoriter, dengan paksaan ataupun kekerasan; yang terpenting adalah menanamkan pengertian sehingga timbul kesadaran untuk melakukan sesuatu sesuai nilai-nilai yang berlaku. Menghadapi atlet yang kurang disiplin perlu dilakukan pengawasan yang ketat, bahkan kalau perlu dengan sangsi-sangsi; namun pada akhirnya keberhasilan pembinaan disiplin tersebut akan sangat tergantung pada berhasilnya menumbuhkan pengertian dan kesadaran agar atlet itu sendiri pada akhirnya mematuhi nilai-nilai atas kehendak dan kesadarannya.

Dalam cabang olahrag senam artistik sikap disiplin sangat penting, karena senam artistik adalah senam ketangkasan yang memiliki tingkat cedera cukup tinggi. Jika atlet tidak disiplin dalam mengikuti latihan sesuai dengan instruksi pelatih, maka akan dimungkinkan atlet tersebut bisa cedera. Misalnya sebelum melakukan rangkaian gerakan, atlet harus secara maksimal dan disiplin diri untuk melakukan peregangan dan pemanasan secara individu tanpa harus diawasi oleh pelatih atau teman-teman. Terutama pada bagian kelenturan, jika atlet malas dan tidak melakukan pemanasan karena tidak ada teman, maka atlet tersebut belum bisa meakukan gerakan, karena bisa menyebabkan robek oto atau cederalainnya.

\section{METODE PENELITIAN}

Metode dalam penelitian ini adalah kualitatif. Menurut Sugiyono (2006) Penelitian kualitatif adalah penelitian yang digunakan untuk meneliti pada kondisi objek alamiah, dimana peneliti merupakan instrumen kunci. Penelitian ini bermaksud untuk memahami fenomena tentang apa yang dialami oleh subjek penelitian misalnya perilaku, persepsi, motivasi, tindakan, dll secara holistic, dan 
dengan cara deskripsi dalam bentuk kata-kata dan bahasa, pada suatu konteks khusus yang alamiah dan dengan memanfaatkan berbagai metode alamiah. data dalam penelitian ini diolah dengan analisisDeskriptif. Menurut Barlian (2016) analisis data kualitatif adalah menggunakan kata-kata yang bisa disusun dalam teks yang diperluan atau melakukan anaisis dari data yang diambil dari data yang ada dilapangan dan selanjutnya dideskripsikan dalam bentuk narasi. Jadi dalam penelitian ini, peneiti hanya menceritakan tentang bagaimana keadaan yang ada dilapangan berdasarkan hasil wawancara dan observasi peneiti.

\section{HASIL PENELITIAN}

Dari hasil penelitian melalui observasi dan wawancara pada diKabupaten Sijunjungdapat digambarkan bahwa masih kurang diperhatikannya faktof psikologi pada atlet senam artistik) atlet sering merasa cemas, sehingga atlet tidak konsentrasi dalam melakukan gerakan, atlet juga tidak bisa melakukan gerakan dengan benar sehingga atlet sering terjatuh. Serdangkan jika dilihat pada alat lantai, terlihat atlet masih kaku dalam melakukan gerakan,hal ini disebabkan oleh atlet merasa cemas saat dicemooh oleh teman-teman atau pelatihnya. Pada aspek agresifitas gterlihat bahwa sebagian besar atlet senam artitik di Kabupaten Sijunjung masih kurang agresif, atlet hanya melakukan gerakan yang diinstruksikan oleh pelatih, namun setelah selesai atlet masih banyak terlihat sedang bermain dan kurang fokus dalam latihan.

Pada aspek motivasi, peneliti melihat bahwa motivasi yang dimiliki atlet masih rendah untuk biasa mencapai prestasi yang tinggi, hal ini terlihat saat latihan atlet kurang semangat dan hanya menunggu teman dalam latihan, jika tidak ada teman atlet memilih untuk tidak latihan. Dan duduk melihat atlet lain melakukan latihan.Pada aspek kecerdasan, terlihat bahwa atlet masuh kurang memanfaatkan aspek keserdasan yang dimilikinya dalam latihan, hal ini terlihat bahwa atlet thanya menunggu intruksi pelatih dalam melakukan gerakan, seperti gerakan salto kedepan, namun atlet tidak menganalisis dan mencari solusi sendiri dimana kekurangan teknik yang dilakukannya itu. Sedangkan pada aspek percaya diri, terlihat bahwa atlet masih kurang memiliki percaya diri karena saat melakukan gerakan, atlet masih malu-malu dalam latihan maupun malu untuk bertanya tentang kekurangan gerakan yang dilakukannya. Disini atlet terlihat hanya menunggu masukan dari pelatih atas kekurangan gerakan yang dilakukannya.disini juga terlihat atlet merasa belum sanggup untuk melakukan gerakan-gerakan baru yang lebih sulit yang disuruh oleh pelatih.

Dari aspek ketegangan, dapat dilihat bahwa atlet masih tegang dalam melakukan gerakan yang sulit, hanya sebagain kecil atlet yang santai dan enjoy dalam melakukan gerakan. Sedanhkan bnahak dari talet yang masih merasa tegang dan sgtress dalam melakukan geraka yang memiliki tingkat kesulitas yang lebih tinggi sebelumnya. Pada aspek rasa Cemas, terlihat bahwa masih banyak atlet yang merasa cemas dalam melakukan gerakan baru yang lebih sulit, rasa cemasnbisa muncul pada atlet sebelum pertandingan dan sesudah pertandingan. Perasaan cemas yang dirasakan oleh setiap atlet berbeda antara satu dengan yang lainnya, biasanya disebabkan oleh pengalaman dari setiap atlet. Sedangkan aspek disiplin, pada atlet sudah memiliki tingkat disiplin yang tinggi, artinya atlet masih tetap latihan jika ada datau tidak ada pelatih, atlet sudah mmeulai epregangan dan pemanasan sendiri atau secara berkelompok dengan teman-temannya, sehingga 
tidak perlu diawasi oleh pelatih lagi, namun jika sudah mampelajari gerakan baru yang lebih sulit, maka disiplin atlet akan sedikit menurun, mkin disebabkan oleh faktor psikologi lain yang sudah dibahas sebelumnya. Dari penelitian yang dilakukan peneliti dilapangan terlihat bahwa faktor psikologi masih kurang diperhatikan oleh pelatih dan pengurus senam artistik di kabupaten Sijunjung.

\section{PEMBAHASAN}

Berdasarkan penelitian dilapangan, terlihat masih kurangnya diperhatikan aspek psikologi atlet senam di Kabupaten Sijunjung. Hal ini terlihat dari banyaknya indikator psikologi yang masih berada dalam keadaan kurang.Seperti emosi, pelatih masih perlu melakukan stimulus dan respon terhadap emosi atlet, sehingga atlet memiliki pengendalian emosi yang baik dalam bertanding maupun dalam latihan. Hal ini salah satunya bisa dilakukan pelatih dengan mengadakan studi banding ke tempat senam lain, dan aktif mengikuti kejuaraan mulai dari tingkat daerah hingga nasional. Untuk aspek agresifitas pada atlet,karena masih kurang juga bisa ditingkankan oleh pelatih melalui memotivasi atlet agar lebih baiksehingga mencapai prestasi yang lebih tinggi dengan memberikan kata-kata penguatan kepada atlet.

Untuk aspek kecerdasaan, setiap atlet memiliki tingkat kecerdasan yang bebeda-beda, sehingga dengan begitu pelatih harus bisa mmebuat program latihan dengan baik untuk mengembangkan potensi yang dimiliki atlet sesuai dengan kebutuhannya masing-masing. Cara atlet memahami intruksi pelatih juga menandakan tingkat kecerdasan atlet tersebut. untuk mendukung hal tersebut pelaitih harus mempelajari lebih banyak tentang model atihan yang bisa meningkatkan keterampilan atlet, sehingga dengan keterampilan yang baik, atlet akan memiliki percaya diri yang tinggi, dan rasa cemas yang dimiliki atlet akan berkurang. Rasa cemas bisa muncul pada atlet sebelum pertandingan dan sesudah pertandingan. Perasaan cemas yang dirasakan oleh setiap atlet berbeda antara satu dengan yang lainnya, biasanya disebabkan oleh pengalaman dari setiap atlet. Hal ini juga tidak terlepas dari disiplin yang kuat yang ditanamkan oleh pelatih saat latihan. Misalkan penanaman model disiplin, keterlambatan, bagi atlet yang terlambat akan diberikan pengembangan berupa latihan fisik oleh pelatih.

\section{SIMPULAN}

Berdasarkan uraian di atas mengenai hasil penelitian yang telah dilakukan serta pembahasan yang telah di kemukakan, dapatdi tarik kesimpulan sebagai berikut:Psikologi olahraga merupakan salah satu cabang ilmu psikologi yang mengkaji secara khusus faktor-faktor psikologi yang berpengaruh dan menunjang penampilan atau kinerja fisik dalam berolahraga dan bagaimana peran dalam latihan dapat mempengaruhi perkembangan aspek psikologi seseorang atlet. Aspek psikologi sangat dibutuhkan dalam mendukung presasi atlet senam artistik. Faktor psikologi meliputi; motif-motif berprestasi, intelegensi, aktualisasi diri, kemandirian, agresivitas, emosi, percaya diri, motivasi, semangat, rasa tanggungjawab, rasa sosial, hasrat ingin menang dan sebagainya. Aspek-aspek psikis yang berpengaruh dan dapat dikembangkan pada diri atlet adalah kemantapan emosi, keuletan (agresif), motivasi dan semangat, disiplin, percaya diri, keterbukaan, dan kecerdasan. 
Ada beberapa manfaat psikologi olahraga dalam meningkatkan prestasi atlet yaitu dapat menjelaskan dan memahami tingkahlaku atlet dan gejala-gejala psikologik yang terjadi dalam olahraga pada umumnya, dapat meramalkan atau membuat prediksi dengan tepat kemungkinan-kemungkinan yang dapat terjadi pada atlet, berkaitan dengan permasalahan psikologik, dan dapat mengontrol dan mengendalikan gejala tingkah laku dalam olahraga; dengan perlakuan-perlakuan untuk menanggulangi hal-hal yang kurang menguntungkan, juga dapat memberi perlakuan-perlakuan untuk mengembangkan kemampuan dan segi-segi positif yang dimiliki atlet senam artistik.

\section{DAFTAR RUJUKAN}

Barlian, (2016). Metode Penelitian Kualitatif. Padang : Suka Bina Press

Cooper L. (1969). Athletics, activity, and personality. A review a literature dlm Research Quartely : 40, 17-22.

Cox, R.H. (1986). Sport Psychology: Concepts and applications. Dubuque, IA: Brown \& Benchmark.

D. Gunarsa, Singgih (2004). Psikologi Olahraga Prestasi. PT BPK Gunung Mulia.

Drever, James. (1971). A Dictionary Of Psicology. New York :Peguin Books.

Fisher, A.C. (1976). Phychology of Sport. Palo Alto: Mayfiel Publ. Co. Foundations of Sport and Exercise Psychology. Champain IL: Human Kinetics.

Singer. R.N. (1980). Motor Learning and Human Performance. London: Collier Macmillan Publishers

Sudibyo, S. (1993). Psikologi Kepelatihan. Jakarta:CV Jaya Sakti

Sugiyono . (2006). Metode Penelitian Bisnis, Cetakan Kesembilan. Bandung. CV. Alfabeta

Sukadiyanto. (2011). Pengantar Teori dan Metodologi Melatih Fisik. Bandung: CV. Lubuk Agung

Syafrudin. (2011). Teori Kepelatihan Olahraga. Padang: FIK UNP.

Undang-undang Republik Indonesia No. 20 tahun 2003. Tentang Sistem Pendidikan Nasional.

Weinberg, R. S. \& Gould, D. (1995). Foundations of Sport and Exercise Psychology. Champain IL: Human Kinetics. 